\title{
The Muppets bringing child resilience into Middle Eastern humanitarian work
}

The makers of Sesame Street are working with a global humanitarian agency to try to help children
affected by conflict and displacement. Ingrid Torjesen reports Ingrid Torjesen freelance journalist

Six year olds Basma and Jad are best friends. Basma is a purple furred Muppet who loves to sing and dance. Jad has yellow fur and likes art. Followed around by a pet goat called Ma'zooza, who eats anything shaped like a circle and causes chaos, they have fun and adventures together.

This may seem similar to any other TV show for 3-8 year olds, but specialists in child development and trauma helped create the characters and content in Ahlan Simsim (Welcome Sesame) to support the social and emotional development of displaced children in Syria, Iraq, Jordan, and Lebanon.

\section{For displaced families}

The program is part of an initiative offering mass media and direct services for displaced families by Sesame Workshop, the US non-profit organization that produces Sesame Street, in collaboration with the International Rescue Committee (IRC), a global humanitarian organization. The John $\mathrm{D}$ and Catherine T MacArthur Foundation awarded the initiative £10om (€110m; \$130m) to transform the way humanitarian systems serve children affected by crisis. Before developing the content, Sesame consulted child development and educational experts, humanitarian organizations working in the refugee camps, and parents and children living there.

The new Muppets have special powers: Basma can create sounds with her hands and Jad, who is new to the area, can paint in midair. "They use these as non-verbal sensory ways to describe how they're feeling," says Shanna Kohn, senior manager of education for Sesame's humanitarian program.

Development of children's social and emotional skills is as important as development of their academic skills. The first season of the program focused on managing emotions such as anger, sadness, jealousy, and fear through coping strategies-for example, breathing techniques and expressing emotions through art. Kohn describes these as "the ABCs of social and emotional learning” that will continue through the remaining three seasons.

The second season, airing now, deals with challenges presented by covid-19, such as isolation. Season three will deal with social skills and conflict resolution, and season four will focus on perseverance, optimism, and hope.

\section{Community focused}

One of the experts Sesame consulted was Reem Khamis-Dakwar, professor of communication sciences and disorders at Adelphi University, Garden City, New York.

"Every decision made in the design of the program and its production was based on the evidence and review of culturally and linguistically relevant studies and knowledge," she says.

Khamis-Dakwar, a Palestinian who studied in Israel, was impressed by the depth of Sesame's consultation to reach expert consensus. "It was all in Arabic," she says. "That tells me that they're looking at the community."

"It's really important that the kids really connect." Children can relate to the program, she says, because the characters look like them, dress like them, talk like them, and even eat the same food as them.

During production, Sesame tests all its programs with small groups of children and parents for appeal, for developmental and cultural relevance, and to make sure that educational messages are understood.

The program is broadcast on the pan-Arab $\mathrm{MBC}_{3}$ satellite channel and local stations across the region. Episodes and bonus content are also available on YouTube. Many families in refugee camps have bought a television and a satellite dish, says Kim Foulds, senior director of international research and evaluation at Sesame Workshop, as there are few other distractions for families. Parents often watch the program with their children, she says.

\section{Multifaceted initiative}

The program is part of a multifaceted initiative to support the emotional development of children who have experienced extreme trauma, with services delivered by the IRC.

The IRC runs year long preschool "healing classrooms" that aim to promote a sense of security, safety, and belonging and offer play based, developmentally appropriate learning activities to help children prepare for primary school. Videoclips from Ahlan Simsim are shown, and activities are linked to characters and storylines.

Such formal programs cannot run in less stable areas, such as north east Syria, but the IRC establishes informal play and learning sessions in community centres and health clinics, and home visits support 
parents, explains Katie Murphy, the IRC’s senior technical adviser for early childhood development.

"The covid-19 pandemic has forced us to rely much more heavily on digital and phone based engagement," she adds, so phone calls and tailored text messages from teachers and facilitators have replaced home visits. Messages focus on play and learning activities and promoting children's wellbeing as well as information about covid-19 and hygiene.

The IRC says attending Ahlan Simsim activities at its centres helps reduce the impact of psychological stress among children who have experienced conflict, displacement, and familial loss.

Muthanna Samara, professor of psychology at Kingston University, London, thinks Ahlan Simsim is "a very good initiative."

It explains the emotions that young displaced children may be experiencing in a way they can understand, he says, such as fear of the dark on movie night and frustration when friends don't want to play or don't play by the rules. It incorporates tried and tested techniques for helping traumatized children to express themselves, such as art and play therapy, and teaches them simple coping strategies such as "belly breathing," he says.

"When you have hundreds, thousands, millions of refugees, you cannot do this individually with each child," he says.

Samara's research has shown cumulative exposure to violence may increase children's likelihood of developing mental health, emotional, and behavioral problems, ${ }^{1}$ and that positive parenting and strengthening children's emotional intelligence and friendships can help reduce mental health problems. ${ }^{23}$

\section{Independent evaluation}

Hirokazu Yoshikawa, professor of globalization and education, co-director of the Global TIES for Children Center at New York University, and co-chair of the network on early childhood development for the UN's sustainable development goal 4, is leading an independent evaluation of the initiative's effect. "The humanitarian sector has traditionally not had an emphasis on early childhood development and learning that goes beyond survival," he explains. "Most of the early work has been around basic health, nutrition, and shelter."

"The point of this initiative was to think about early childhood development more broadly, to think beyond survival on to helping children thrive. So, to think about health and nutrition, but also learning and social and emotional development."

The evaluation will use vignettes to assess children's ability to identify emotions in different situations and come up with coping strategies, he explains. Children will be asked how characters might feel and what they might do, and how they themselves might feel and what they might do in a similar scenario. In Jordan, this is being conducted in the context of a randomized controlled trial, with preschools randomly assigned to using Ahlan Simsim materials or to the government curriculum.

The IRC's Murphy says: “One of our overall ambitions is not just that this improves the lives of individuals within the four countries but that we are able to demonstrate that early childhood interventions can be effective, cost effective, and used at scale.

"We can shift the humanitarian response so that these types of approaches become core to any emergency response."
Provenance and peer review: Commissioned; not externally peer reviewed.

This article is part of a series commissioned by The BMJ for the World Innovation Summit for Health (WISH) 2020. The BM/peer reviewed, edited, and made the decisions to publish. The series, including open access fees, is funded by WISH.

1 El-Khodary B, Samara M. The relationship between multiple exposures to violence and war trauma, and mental health and behavioural problems among Palestinian children and adolescents. Eur Child Adolesc Psychiatry 2020;29:719-31.

doi: 10.1007/s00787-019-01376-8. pmid: 31352503

2 El-Khodary B, Samara M. The mediating role of trait emotional intelligence, prosocial behaviour, parental support and parental psychological control on the relationship between war trauma, and PTSD and depression. J Res Pers 2019;81:246-56. doi: 10.1016/j.jp. 2019.06.004.

3 Samara M, El Asam A, Khadaroo A, Hammuda S. Examining the psychological well-being of refugee children and the role of friendship and bullying. Br J Educ Psychol 2020;90:301-29. doi: 10.1111/bjep.12282. pmid: 31056751

This is an Open Access article distributed in accordance with the Creative Commons Attribution Non Commercial (CC BY-NC 4.0) license, which permits others to distribute, remix, adapt, build upon this work non-commercially, and license their derivative works on different terms, provided the original work is properly cited and the use is non-commercial. See: http://creativecommons.org/licenses/by$\mathrm{nc} / 4.0 /$. 